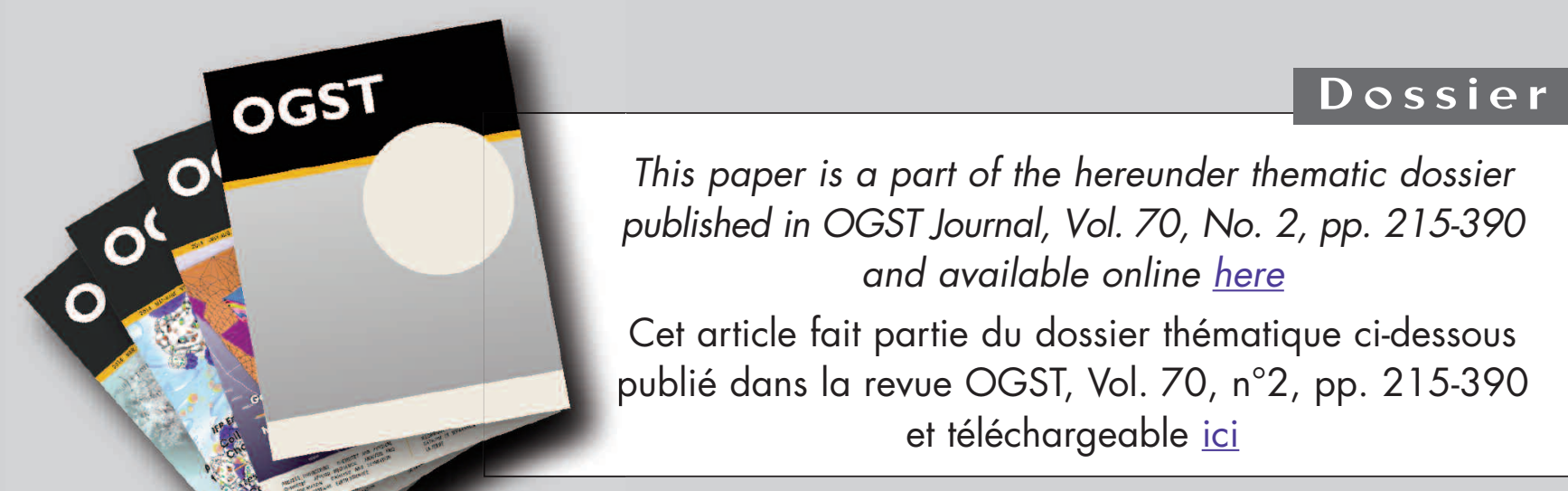

DOSSIER Edited by/Sous la direction de : B. Dewimille

Fluids-Polymers Interactions: Permeability, Durability

Interactions fluides polymères : perméabilité, durabilité

Oil \& Gas Science and Technology - Rev. IFP Energies nouvelles, Vol. 70 (2015), No. 2, pp. 215-390

Copyright (C) 2015, IFP Energies nouvelles

$215>$ Tribute to Yves Chauvin Hommage à Yves Chauvin

S. Candel and 0 . Appert

$219>$ Editorial

G. Kimmerlin

227 > Gas Permeation in Semicrystalline Polyethylene as Studied by Molecular Simulation and Elastic Model

Perméation de gaz dans le polyéthylène semi-cristallin par simulation moléculaire et modèle élastique

P. Memari, V. Lachet and B. Rousseau

237 > Reinforcement of the Gas Barrier Properties of Polyethylene and Polyamide Through the Nanocomposite Approach: Key Factors and Limitations

Renforcement des propriétés barrière aux gaz de matrices polyéthylène et polyamide par l'approche nanocomposite : facteurs clés et limitations E. Picard, J.-F. Gérard and É. Espuche

251 > Diffuso-Kinetics and Diffuso-Mechanics of Carbon Dioxide / Polyvinylidene Fluoride System under Explosive Gas Decompression: Identification of Key Diffuso-Elastic Couplings by Numerical and Experimental Confrontation

Cinétique de diffusion et comportement diffuso-mécanique du système dioxide de carbone / polyfluorure de vinylidène sous décompression explosive de gaz : identification des couplages diffuso-élastiques majeurs par confrontation numérique et expérimentale

J.-C. Grandidier, C. Baudet, S. A. E. Boyer, M.-H. Klopffer and L. Cangémi

267 > Characterization of Polymer Layered Silicate Nanocomposites by Rheology and Permeability Methods: Impact of the Interface Quality

Caractérisation de nanocomposites polymère silicate par des méthodes de rhéologie et de perméabilité : rôle de la qualité de l'interface

R. Waché, M.-H. Klopffer and S. Gonzalez

$279>$ Evaluation of Long Term Behaviour of Polymers for Offshore Oil and Gas Applications

Durabilité des polymères pour application pétrolière offshore

P.-Y. Le Gac, P. Davies and D. Choqueuse

$291>$ Development of Reactive Barrier Polymers against Corrosion for the Oil and Gas Industry: From Formulation to Qualification through the Development of Predictive Multiphysics Modeling

Développement de matériaux barrières réactifs contre la corrosion pour l'industrie pétrolière : de la formulation à la qualification industrielle en passant par le développement de modèles multiphysiques prédictifs

X. Lefebvre, D. Pasquier, S. Gonzalez, T. Epsztein, M. Chirat and F. Demanze
$305>$ Development of Innovating Materials for Distributing Mixtures of Hydrogen and Natural Gas. Study of the Barrier Properties and Durability of Polymer Pipes

Développement de nouveaux matériaux pour la distribution de mélanges de gaz naturel et d'hydrogène. Étude des propriétés barrière et de la durabilité de tubes polymères

M.-H. Klopffer, P. Berne and É. Espuche

317 > New Insights in Polymer-Biofuels Interaction

Avancées dans la compréhension des interactions polymères-biocarburants E. Richaud, F. Diouani, B. Fayolle, J. Verdu and B. Flaconneche

$335>$ Biofuels Barrier Properties of Polyamide 6 and High Density Polyethylene Propriétés barrière aux bio essences du polyamide 6 (PA6) et du polyéthylène haute densité (PEHD)

L.-A. Fillot, S. Ghiringhelli, C. Prebet and S. Rossi

353 > Permeability of EVOH Barrier Material used in Automotive Applications: Metrology Development for Model Fuel Mixtures

Perméabilité d'un matériau barrière EVOH utilisé dans des applications automobiles : développement métrologique pour des mélanges modèles de carburants

J. Zhao, C. Kanaan, R. Clément, B. Brulé, H. Lenda and A. Jonquières

367 > Effects of Thermal Treatment and Physical Aging on the Gas Transport Properties in Matrimid ${ }^{\circledR}$

Les effets du traitement thermique et du vieillissement physique sur les caractéristiques du transport au gaz dans le Matrimid ${ }^{\circledR}$

L. Ansaloni, M. Minelli, M. Giacinti Baschetti and G. C. Sarti

381 > Separation of Binary Mixtures of Propylene and Propane by Facilitated Transport through Silver Incorporated Poly(Ether-Block-Amide) Membranes Séparation de mélanges binaires de propylène et de propane par transport au travers des membranes de poly(éther-blocamide) incorporant de l'argent R. Surya Murali, K. Yamuna Rani, T. Sankarshana, A. F. Ismail and S. Sridhar 


\title{
Forward
}

\section{TRIBUTE TO YVES CHAUVIN}

As we completed this issue of OGST Revue d'IFP Energies nouvelles dedicated to polymer materials, we learned with great sadness the death of Yves Chauvin. His research, carried out in the laboratories of IFP Energies nouvelles, led him in 1971 to provide the mechanism for the metathesis of olefins, a synthesis reaction that involves the two pairs of double bonds of electrons between two carbon atoms. Groups of atoms, themselves carried by these two atoms, can move from one molecule to another. The metathesis reaction can be represented with an analogy with "two pairs of dancers who form a square and then exchange their respective partners to lead to two new pairs of dancers". This major discovery revolutionized chemistry and catalysis sciences, since it allowed to exploit the enormous potential of the metathesis reaction and has led to industrial applications in various fields such as refining, pharmaceuticals or production of polymeric materials. For this scientific discovery, Yves Chauvin was awarded the 2005 Nobel Prize in Chemistry with Robert H. Grubbs (Caltech, USA) and Richard R. Schrock (MIT, USA).

Yves Chauvin's talent was not only exercised on metathesis. His work led to the emergence of a French school of homogeneous catalysis, built and developed in collaboration with academic laboratories. His research has resulted in both major scientific advances and industrial achievements operated worldwide.

Throughout his career, Yves Chauvin was concerned with the transmission of his curiosity and his knowledge for the training of young researchers. Many publications are issued from the work of Yves Chauvin and some have been published in this journal (Oil Gas Science and Technology 37 (1982) 5, 639-649). The scientific influence of Yves Chauvin work has also been the subject of a special issue of OGST in 2007 (Oil Gas Science and Technology 62, 6, 727-825) and an upcoming issue of OGST is in preparation to celebrate new scientific advances derived from this work.

IFP Energies nouvelles and the Editorial Board of OGST salute the memory of a great scientist.

\author{
Sébastien Candel \\ Vice President of the French Academy of Sciences - \\ Chairman of the Editorial Board of OGST \\ Olivier Appert \\ Chairman and CEO of IFP Energies nouvelles
}





\section{Préambule}

\section{HOMMAGE À YVES CHAUVIN}

Au moment où nous bouclions ce numéro d'OGST - Revue d'IFP Energies nouvelles consacré aux matériaux polymères, nous apprenions avec une grande tristesse le décès d'Yves Chauvin. Ses recherches, menées dans les laboratoires d'IFP Energies nouvelles, le conduisirent en 1971 à proposer le mécanisme de la métathèse des oléfines, une réaction de synthèse qui met en jeu les deux paires d'électrons de liaisons doubles entre deux atomes de carbone. Les groupes d'atomes, eux-mêmes portés par ces deux atomes, peuvent passer d'une molécule à une autre. La réaction de métathèse peut être représentée de façon imagée par « deux couples de danseurs qui se mettent en carré puis échangent leurs partenaires respectifs pour conduire à deux nouveaux couples de danseurs ». Cette découverte majeure va révolutionner la chimie et la catalyse puisqu'elle va permettre d'exploiter le potentiel énorme de la réaction de métathèse et conduire à des applications industrielles dans des domaines très variés comme le raffinage, la pharmacie ou la production de matériaux polymères. Pour cette découverte scientifique, Yves Chauvin s'est vu attribuer en 2005 le prix Nobel de Chimie avec Robert H. Grubbs (Caltech, USA) et Richard R. Schrock (MIT, USA).

Le talent d'Yves Chauvin ne s'est pas exercé uniquement sur la métathèse. Ses travaux ont conduit à l'émergence d'une école française de la catalyse homogène construite et développée en collaboration avec des laboratoires académiques. Ses recherches ont abouti à la fois à des avancées scientifiques majeures et à des réalisations industrielles opérées dans le monde entier.

Tout au long de sa carrière, Yves Chauvin a été soucieux de la transmission de sa curiosité et de son savoir pour la formation des jeunes chercheurs. De nombreuses publications sont issues des travaux d'Yves Chauvin et certaines ont été publiées dans cette revue (Oil Gas Science and Technology 37 (1982) 5, 639-649). Le rayonnement scientifique des travaux d'Yves Chauvin a également fait l'objet d'un numéro spécial d'OGST en 2007 (Oil Gas Science and Technology 62, 6, 727-825) et un prochain numéro d'OGST est en préparation pour souligner les nouvelles avancées scientifiques issues de ces travaux.

IFP Energies nouvelles et le Comité Éditorial d'OGST tiennent à saluer la mémoire d'un grand scientifique.

Sébastien Candel

Vice-Président de l'Académie des Sciences Président du Comité Éditorial OGST

Olivier Appert

Président d'IFP Energies nouvelles 
